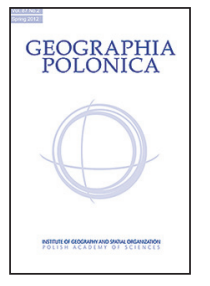

\title{
BORDER CHANGES IN CENTRAL AND EASTERN EUROPE: AN INTRODUCTION
}

\author{
Vladimir Kolosov ${ }^{1}$ - Marek Więckowski ${ }^{2}$ \\ ${ }^{1}$ Institute of Geography \\ Russian Academy of Sciences \\ Staromonetny pereulok 29, 119017 Moscow: Russia \\ e-mail: kolosov@igras.ru \\ ${ }^{2}$ Institute of Geography and Spatial Organization \\ Polish Academy of Sciences \\ Twarda 51/55, 00-818 Warsaw: Poland \\ e-mail: marekw@twarda.pan.pl
}

\begin{abstract}
The objective of this paper is to consider the main border issues and cross-border relationships in Central and East Europe (CEE) in the context of changing theoretical approaches to border studies. The authors start by analysing the impact of the impressive progress in the theory of borders on studies of CEE. Fundamental political changes in this part of Europe after 1989 were associated with the opening of borders and the intensification of cross-border cooperation, which have radically transformed the functions of boundaries. Emerging cross-border regions became spaces of communication, interaction, innovations and development. The EU enlargement to the east and the inclusion of most CEE countries in the Schengen zone accelerated the processes of re- and de-bordering and the diversification of the functions and regime of borders. The powerful waves of migration to the European Union over recent years have again greatly modified the situation in border areas and provoked the construction of new walls. In conclusion the authors propose eight research questions for future studies of borders and bordering in CEE.
\end{abstract}

\section{Key words}

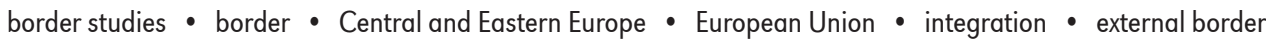
of the European Union $\bullet$ post-Soviet countries $\bullet$ geopolitics

Over the last fifteen or twenty years border studies have become one of the most rapidly developing interdisciplinary fields. This is manifested in the growing number of papers and regular conferences which attract hundreds of participants like BRIT (Border Regions in Transition), Borderscapes, and World Congresses of the International Association of Border Studies (IABS). Borders are the focus of large general conferences like the annual conference of the 
Association of American Geographers in Tam$\mathrm{pa}$, or the 25th Congress of the International Council of Social Sciences and Humanities (CIPSH) in Liège (2017) and the IGU Regional Conference in Krakow (2014).

The large number of events and the research carried out by scientists around the world are the stimulus for the preparation of a thematic issue of GEOGRAPHIA POLONICA concerning border changes in Central and Eastern Europe. The objective of this issue is to go back over borders and cross-border relationships in a context where the traditional representation of borders seen as ground for categorisation and delimitation is now questioned by multiple flow processes, dynamics and change. The idea has been focused on the changing functions of borders as part of bordering and debordering processes. After 1989, the main changes were associated with opening borders and the intensification of cross-border cooperation. Additional regulations were added with the enlargement of the European Union and the Schengen zone. New waves of migration to the European Union in recent years have changed the situation on borderlands and provoked the construction of new walls.

During the last decade the study of borders has moved from a dominant concern with formal state frontiers and ethno-cultural areas to the study of borders at diverse socio-spatial and geographical scales, ranging from the local and the municipal, to the global, regional and supra-state level (Kolosov \& Scott 2013). This unprecedented interest is closely related to impressive progress in the theory of borders. Firstly, they now consider not only the most important political borders separating sovereign states but the single system of borders in society, including tangible dividing lines visible in the landscape, and invisible, social, cultural, linguistic and confessional boundaries on all scales - from a neighbourhood to global macroregions. Secondly, the production and modification of these dividing lines is viewed as a basic social need in the separation of 'us' from 'them', the Others, who are different and often threaten 'our' very existence, i.e. 'our' autonomy and self-organisation as specific social groups, clans, tribes, kingdoms and states, necessary to protect 'us' and to keep a relative social order. So, thirdly, borders are an intrinsic element of territorial identity and are not fixed lines in space but their allocation, delimitation and demarcation, their regime and functions strongly depend on their interpretation by the people, their symbolic role. In its turn, it is determined by the interests of the elite wishing to control a territory and political institutions, the process of socialisation, media policy and representations on neighbouring countries and their population, personal experience of various social groups and 'border rent', i.e. the material and non-material profit from a border crossing (Stryjakiewicz 1998; Gorzelak 2006; Elden 2010). It is concluded that borders are a very dynamic phenomenon whose functions and regime are constantly constructed in the course of practically all forms of human activity. This process was called bordering, or rebordering and de-bordering, depending on the circumstances.

This conclusion means that borders are everywhere and most social phenomena can be considered through the lenses of bordering. Such a view opened an incredible diversity of new themes for scholars - from the role of art in reflecting and constructing borders to gender problems related to a border crossing. Originally a field that was primarily a domain of geographers, the cognitive approach to border studies offered fascinating new research perspectives for other social scholars - historians and economists, sociologists and specialists in international relations. Virginie Mamadouh (2015) even speaks about an epidemic of borderitis ("borders are everywhere and everything is bordering"). Nowadays national borders are generated inside the state territory: at international airports, in transportation nodes, around special customs areas, and free economic zones. Border control is relocated to other places within state territories, and inside the Schengen zone police can check documents anytime and at any geographical point in a country. As a result of these processes, border space no longer exclusively embraces the physical limits of the state but is extended to all the territory. 
But, of course, 'borderitis' emerged not only from the autonomous and isolated development of social thought in a social vacuum but is a result of fundamental geopolitical shifts that occurred in the 20th century and continue until today: two world wars, decolonisation, the rise and the fall of the 'socialist world', the development of economic and political integration and the crisis of international migrations. The world political map was radically rearranged and a great number of new sovereign states were created, which transformed the world system of boundaries (Foucher 2005). Because of these transformations, Europe, often called 'the old continent', became the region with the 'youngest' political borders (Foucher 1991, 2005), though some European boundaries are the oldest in the world. The very notion of contemporary borders and the Westphalian geopolitical order appeared in Europe. This paradox is a legacy of world wars which affected Europe much more than other regions in the world. The general result of post-World War I geopolitical transformations was geopolitical fragmentation: the creation of new small and medium states (Hungary, Czechoslovakia, Poland, Yugoslavia), the loss of territory by Germany (Eberhardt 2015, 2017) and therefore, of new borders. This process is observed in Europe, as well as elsewhere, until today, accelerating in critical periods, for example in the years of decolonisation (the late 1950s - the early 1960s), and slowing down in years of relative stability.

World War Two led to a considerable new transformation of European borders as a result of such important geopolitical changes such as the 'shift' of Polish territory to the west, the creation of two German states and the partition of the former East Prussia between the Soviet Union and Poland etc., and perhaps most importantly, the division of Europe by the 'iron curtain'. Due to the shift of Polish territory the length of the country's boundaries also decreased, shrinking from $5,529 \mathrm{~km}$ in 1938 to $3,560 \mathrm{~km}$ in 1945 , that is - by $1,969 \mathrm{~km}$ (35.4\%). Most post-war boundaries were new (i.e. the Polish-German boundary on the rivers Oder and Nysa Łużycka and almost the entire boundary between Poland and the Soviet Union). Political decisions and changes in boundaries provoked large-scale waves of migration. Population in border towns dropped and the settlement system changed. New boundaries cut transport networks, broke social and economic networks and contributed to the isolation of border regions which faced additional problems in the development of infrastructure and lacked investment. Borders became clear-cut barriers to flows of people. Its consequences are clearly seen today in demography and the economy, the internal structure of former socialist countries and particularly in the conditions and premises of cross-border cooperation on different borders (see the papers in this issue by Żupancić et al. 2018, and by Dołzbłasz 2018). It changed the very notion of borderland formerly closely associated with periphery, suffering from isolation and backwardness, totally dependent on the decisions taken by the central government. The specific interests of borderlands and their economic development were sacrificed for the sake of national security, even if they were settled by ethnic minorities; they were transformed into glacis hosting border police, customs and military garrisons.

Later, European integration became a major factor in the change of the functions of their internal and external border functions, profoundly modifying their symbolic meaning and socio-political significance. The opening of internal boundaries to free circulation of people, goods, capital and information were crucial to the project of the European Union as a community transcending national borders, historical conflicts and contradictions, and built on the principles of common values and identity, and on jointly adopted norms and rules. The progress of European integration contributed to the transformation of many borderlands into locomotives of economic development and innovation. It was based on increasing economic interdependence, cooperation between economic agents, mutual investments and intensive flows of goods and migrants, and finally, structural policies, particularly the Cohesion policy 
(Faludi 2015). Internal borderlands benefitted from special efforts enhancing the creation of transnational networks, the development of a post-industrial innovative economy, the involvement of private business and the third sector in cross-border cooperation with the objective of transforming the boundaries between the member countries from frontières coupures to frontières coûtures, i.e. to build an integrated settlement system and economic space.

At the same time, European institutions strengthened the regime of external borders considered as a fence against illegal flows, primarily migrants (Coles et al. 2005) and other mobility patterns (Więckowski 2008). However, they were concerned by the risks provoked by excessive differences in well-being on the external boundaries - political and social instability, and potential 'soft' threats.

The fall of the Berlin wall and the dissolution of the so-called world socialist system in 1989-1990, and the disintegration of the Soviet Union, and then of Yugoslavia and Czechoslovakia caused a new phase of border change in Europe which initially affected its Central-Eastern part. As historical maps show, Central-East Europe (CEE) is a region of most frequent border change. Most countries in this area were located on the edge of the multinational great powers which disputed control over it - the Austro-Hungarian, the Russian and the Ottoman empires, and at a certain stage, the Polish-Lithuanian kingdom. Each of them knew periods of greatest extent when they embraced most of the territory of what it is today called Central Europe. This area was called 'Europe-in-between', and it is not by chance that in each country and in each historical period they delimited Central and East Europe in a different way (O'Loughlin 2001). The lines of separation between them often moved depending on their political and military success. Former political borders became 'scars of history' (an expression of Robert Schuman) and often crossed areas populated by the same ethnic group, dividing them, and thus generating specific identities, e.g., the borders between Slovakia and Hungary (Świątek 2002) or Poland and Lithuania (Barwiński \& Leśniewska 2014).

The early 1990s brought a radical change in the functions of boundaries, the status of border zones and the character of crossborder relationships. At the same time, new interactions became a primary focus of crossborder collaboration and integration. After 1989, the opening-up of borders contributed to an increase in cross-border flows of goods provoked by differences between neighbouring areas in economic regime, prices, etc. Since that time the decisive element underpinning the crossing of borders has been human need, alongside people's capacities to actually make crossings - such elements as an interest in trade, shopping, or leisure on the opposite side of the boundary.

Several waves of EU and NATO eastward enlargement took place in the 2000s and gave rise to specific problems of cohesion and cross-border cooperation between the 'old' and 'new' member states, but especially between 'new' members themselves, and moved the external EU boundary far to the east and south. In 2007 most CEE countries entered the Schengen zone, which significantly contributed to all forms of cross-border cooperation between them. Systemic political and socio-economic changes in the CEE parallel to the opening of the boundaries deeply transformed their regime and functioning, and had a big impact on borderland areas. They increased the significance of borderlands and stimulated new cross-border relationships. Funding from the European Union was the main component of investments in border areas in many CEE regions (Dołzbłasz 2013, 2018). Many authors showed a much greater economic dynamism in the western regions of Hungary, Czechia and Poland bordering 'old' EU members as compared with the eastern ones. This neighbourhood helped to use the endogenous potential of regions more efficiently and became a source of innovation, opened up their transit facilities and created new emerging cross-border regions (Anderson 2000), new cross-border metropolitan regions (Sohn \& Reitel 2016) and new Euroregions in 
CEE (Więckowski 2002). A new situation in Europe produced various types of borders and many differences between them and borderland areas. "These stark differences between 'inclusion' and 'exclusion' reflect and reinforce the varying communist legacies and trajectories of post-communist development in the different parts of Central and Eastern - that is post-Soviet - Europe" (Herrschel 2011: 5).

With the opening of the EU's internal borders, both physically and symbolically, crossborder regions have become spaces of communication, interaction, and development where tourism supports regional identity and image building (Prokkola 2008), and is being transformed into a salient element of crossborder heritage (Prokkola \& Lois 2016). Nilsson et al. (2010) analysed how identities are re-presented and re-negotiated in cross-border destinations.

By another token, the 'ossification' of these countries' eastern borders, now external EU borders of the strict Schengen regime, broke recently formed and still relatively weak transnational economic, social and cultural networks with Ukraine, Belarus and Russia, and hindered cross-border cooperation (Palmowski 2010; Komornicki \& Miszczuk 2010; Wendt 2013; Jakubowski et al. 2017; Miszczuk 2017).

Contemporary borders in Central and Eastern Europe, even if they are fully open (in the Schengen zone), do not disappear, and are not permanently permeable. They can be closed for political (e.g. in case of terrorist attacks or summits), environmental (e.g. the closing of a road or a path in a national park) or other reasons (e.g. sanitary). De facto openness and transparency of the borders depends on the people's mobility cycles - seasonal (annual), weekly and daily, related, in their turn, with the accessibility of national parks, tourist affluence, and other processes. Nevertheless, after a temporary shock provoked by the establishment of the Schengen regime, cross-border interactions between CEE countries - EU members and their eastern neighbours has continued to increase. A particularly important step was the establishment of the local border traffic (LBT) regime on the borders between Belarus and Latvia, Russia and Norway, Russia and Latvia, and Russia and Poland. The decision of the European Parliament, taken in 2006, enabled the member countries to conclude bilateral agreements with their neighbours beyond the limits of the EU simplifying border crossings for citizens who live within the $50 \mathrm{~km}$ strip along both sides of the boundary.

The most successful of these was the creation of the regime between Russia and Poland. It was exceptionally extended to the whole Kaliningrad oblast of Russia and a great number of powiats in two Polish voivodeships - Warminsko-Mazurskie and Pomorskie, including the area of three cities - Gdańsk, Gdynia and Sopot. Between July 2012 and July 2014 alone the consulate of Poland in Kaliningrad issued more than 200,000 cards for regular border crossings. Their number increased between 2010 and 2014 by a ratio of four and reached 6,565 thousand which exceeds the maximum level before the establishment of the Schengen regime. The ratio of Polish and Russian citizens crossing the boundary was shifting in favour of the former and in 2014 the ratio was 65 to 35. According to both Polish and Russian experts, both sides greatly benefitted from this flow, despite some problems. A dense network of professional and human contacts was being created. In particular, Kaliningraders were going to neighbouring Polish cities not only for shopping but also for getting different services, for leisure and to study (see the paper in this issue by Sagan et al. 2018; Gumieniuk et al. 2016).

New geopolitical shifts occurred in Europe and in the world since late 2013 - the crisis in Ukraine, the annexation of Crimea by Russia, the war in the Ukrainian Donbas, the EU sanctions against Russia and its counter-sanctions, Brexit, the growing influence of 'euro-sceptics' and the unprecedented inflow of economic migrants and refugees into Europe which provoked serious differences between EU members - led to new changes in the regime and the functioning of borders in CEE analysed in this issue by James Scott (Scott 2018). 
The situation deteriorated so much that some observers questioned whether a new cold war would arise. Indeed, the balance between the leading players on the international scene, their perception of the threats to national security and their geopolitical codes, i.e. the attitude to their neighbours and the character of relations with them are changing. It led to the erection of physical barriers between CEE countries (in particular, the appearance of new walls on the Hungarian border) to prevent the illegal penetration of migrants onto their territory, the worsening of bilateral relations, the toughening of the border regime with Russia and a decrease in cross-border trade and other flows across its boundaries.

For instance, the events in Ukraine and the devaluation of the rouble in December 2014 reduced the number of crossings between $\mathrm{Ka}-$ liningrad oblast and Poland in 2016 by a third as compared with 2015. Unfortunately, the government of Poland preferred not to restore the local border traffic regime with the Kaliningrad region, despite the protests of the Polish border voivodship authorities. This measure was applied simultaneously and 'temporarily' to Russia and Ukraine because of security reasons in the period of the EU summit in Warsaw, but unlike Ukraine, Russia replied with a reciprocal step, which served as a pretext for this decision.

All in all, the developments in 2014-2017 clearly revealed a lack of East-West convergence, contributed to the perpetuation of controversies between them for the foreseeable future and had a serious impact on crossborder cooperation (Żupancić et al. 2018). These changes are considered as a shift from post-modernism to neo-modernism. First, the state is re-acquiring an exclusive role in international politics that it was apparently losing in favour of other players - regional and local authorities, NGOs etc. Obviously, again the interests of border regions often have a tendency to be ignored. Second, Realpolitik is coming back, and the 'winner' tries to get everything, even if his victory can turn soon into defeat. Third, foreign policy and ambitions seem to dominate economic interests again: the sides involved in a conflict are ready for any sacrifice for the sake of 'national interests' and self-assertion: jobs and profits from export, incomes from tourists and visitors in border regions, and so on. Fourth, a new almost ubiquitous outburst of nationalism can be observed: on the initiative of political leaders, national myths and the claim of a country's exclusiveness, its victimisation is again the focus of media discourse. It darkens attitudes to its neighbours and the conditions of cross-border cooperation. Paradoxically, the complication of the world is accompanied by the simplification of political discourse, an increasingly black and white perception of reality (Kortunov 2017).

Long centuries of struggle for emancipation provoked the creation of strong identities and powerful traditions of political nationalism, exclusiveness and intransigence. Nationalist movements and aspirations striving for the largest possible state territory and feeding stable negative myths and stereotyped representations about neighbours transferred from one generation to another (Kolosov \& O'Loughlin 1998; Laine 2017) are a major risk for the 'Europeanisation' of Central and Eastern Europe.

A political boundary can rarely be erased from a collective historical memory. The configuration of a political territory is a bright and comprehensive image of a country, its brand. Since a technological revolution in printing at the end of the 19th century which made geographical maps affordable for the population, the pattern of state boundaries became part of national and/or ethnic identity. Their representation is a kind of logo for a country widely used in the media and on the covers of school textbooks. Imagination plays a key role in keeping the idea of the historical integrity of the national 'body', merging it with the idea of state sovereignty (Billé 2014; Ushakin 2009). In this respect, public opinion perceives each attempt on this body in an extremely painful manner, be it a claim for few hectares justified by the change of the bed of a border river, or an attempt at secession, or the fragmentation of the state. Such events leave 
a deep mark on people's identity, and affect the geopolitical code of the state's relations with its neighbours. The focus on borders and borderlands as lived spaces has also emerged as an important area of border studies in CEE, in particular, on the Latvian-Estonian-Russian (Assmuth 2003), German-Polish (Mathiessen \& Bürkner 2001) and Russian-Ukrainian border regions (Zhurzhenko 2010; Kolosov \& Vendina 2011; Kolosov et al. 2018).

In developing the association of the state with a human body, they compare the loss of a part of its territory with the amputation of a limb: it does not exist anymore but an individual suffers from phantom pains within it (Gorzelak 2006). Phantom borders are the state borders which lose their most important functions but remain political and cultural barriers visible in different forms of contemporary economic, social and political activity and can be used in the construction or reanimation of territorial identities (Grandits et al. 2015). In people's representations reflecting nostalgia about lost regions, the state's real or imagined grandeur, the country's territory often keeps the configuration that it had in the past. In such cases, enhanced by popular cartographic images, its mental border does not match the existing ones. As Bialasiewicz noticed, phantom borders are an incredibly strong political metaphor reflecting a specific vision of society, a powerful 'container' of particular myths (Bialasiewicz 2009).

This is the case in Hungary considered in detail by James Scott in this issue. Hungary lost $64 \%$ of its population and $72 \%$ of its territory with the Trianon Treaty (1920). Hungarians now live in the border regions of all the neighbouring countries (Romania, Serbia, Austria, Slovakia and Ukraine), and the decision of the Hungarian leadership to extend to them the rights of Hungarian citizens provoked serious tensions and complicates cross-border cooperation (CBC) (Scott 2018).

New institutional forms of cooperation are now available in EU member countries allowing regional and local actors to transcend 'inflexible' political boundaries, like the European Groupings of Territorial Cooperation
(EGTC) (Boulineau 2016). New perspectives of cooperation were opened, for example, between Poland, Finland and their eastern neighbours - Russia, Belarus and Ukraine after the adoption of the European Neighbourhood Partnership Instrument (ENPI). Crossborder cooperation between the countries of the Visegrád Group (V4) and the Baltic States is also developing in many fields like regional development, innovations, infrastructure and tourism (Nilsson 2018; Więckowski \& Ceric 2016). The EU Strategy for the Baltic Sea Region provides a unique framework and opportunity for the region. It was supported by the Baltic Development Forum, which recognised that the Baltic Sea area is integrated by networks of numerous formal and informal transborder organisations and multi-scale interactions. Baltic Euroregions operate across sea borders. Lepik (2009) described the opportunities opened up by the creation of Baltic Euroregions, but also stresses several obstacles to their success. Nilsson et al. (2010) examines the Interreg III program focusing on cross-border Baltic regions and its role in the re-negotiation of identities. Euroregions allow the coordination of cross-border interactions in a way that generates synergism and added value (Cinnéide 2007).

The eastern EU border still remains a significant barrier, even if the defensive character of European borders seemed to virtually disappear (Scott 2018). On intra-EU borders, public and especially central authorities do not interfere so much in local cross-border contacts (directly and indirectly, in establishing different norms and regulation) as in post-Soviet countries. On the contrary, business and NGOs are more involved in such interactions. As a result, such interactions are more balanced, stable and less dependent on political events (Hershell 2011). However, the intensity and 'quality' of cross-border cooperation in Central and Eastern Europe are still much lower than between the 'old' EU members. Some institutions exist mostly on paper. The objective reasons are lower demographic and economic density, but also the historical legacy, in particular, an insufficient historical tradition 
of cross-border networking. Experience shows that it is not enough to open a boundary to accelerate cross-border interaction: non-economic factors, cultural motives and negative stereotypes can be stronger (Leimgruber 2005).

However, it would be wrong to only picture the situation on the eastern borders of Central Europe in dark colours. Ethnic mosaics of population and numerous cross-border minorities can not only complicate cross-border cooperation and contacts, but also greatly contribute to them. Communication (circulation, in terms of Jean Gottmann) and openness are the best medicine against old stereotypes. Borders are an important resource and cross-border interactions can stimulate regional and local development, often on the basis of tourism, shopping and transport (transit). International borders have significant political implications for the development of neighbouring regions, especially in terms of joint governance, planning, marketing and promotion, human mobility, taxes, and the general socio-economic situation.

The situation on the borders of a single country varies a lot; it offers very different conditions for cooperation. As is shown in the papers by Scott (2018), Dołzbłasz (2018), Bar-Kołelis and Wendt (2018), intra-EU borderlands benefit from more favourable factors for cross-border-cooperation than on the borders with Belarus, Ukraine and Russia. Political and institutional conditions play a decisive role in cross-border mobility, funding, networking, the composition of partners and the nature of joint projects (Dołzbłasz 2018). Bar-Kołelis \& Wendt (2018) show new processes changing the situation in some border areas 'from bazaars to a supermarket'.

Despite a deep crisis in the relations between the EU and Russia, the barrier functions on the borders between them have not yet grown significantly. Contacts between border municipalities are not only determined by geopolitical factors. Many experts believe that, for instance, on the Polish-Russian border most partners keep good neighbour relations (Wendt 2013; Domaniewski \& Studzińska 2016). Though the LBT regime is frozen, its positive experience enhanced their aspiration to cooperate. Sanctions and counter-sanctions did not make the partners postpone the official beginning of the new programme period of ENPI.

Anyway, borders, and particularly historical borders, are always attractive for tourists, if only the political and criminal situation around them is stable and they are not affected by a military conflict (Timothy 1995; Wachowiak 2006; Alexandrova \& Stupina 2014; Timothy et al. 2016). In border areas natural heritage, monuments commemorating the events of the historical past - battles with foreign conquerors and the feats of national heroes - are an additional factor of attraction (Balibar 2002). Emerging services, products and mobility associated with the border are based on the 'otherness' associated with crossboundary travel. They are often zones of cultural mixing with unique cultural landscapes. Many borderlands host historic monuments and cities. Border-related 'otherness' is also expressed through different land use, festivities and holidays, distinctive cuisines (culinary tourism) and the variety of merchandise available in shops (shopping tourism). The borderland acquires the status of cultural heritage. The best known example of this is the Great Wall of China, which became the most recognisable monument in China, or the Berlin Wall, one of the main symbols of the Cold war, and the former boundary between FRG and GDR as a whole. There are now 22 museums relating to it in contemporary Germany. There are even museums on such old dividing lines as the boundary of the Roman Empire (limes) (Grin'ko 2016).

Many borders were drawn in lightly populated areas which remained underdeveloped buffers and/or transition zones between neighbouring countries which later turned out to be beneficial for the protection of unique natural landscapes. (Więckowski 2018). Now, these are often areas where wilderness is legally guaranteed on both sides of a border (Więckowski 2013; Ramutsindela 2014). This process began in the interwar period and culminated during the Cold War. The political borders of Central and Eastern Europe cross 
fascinating and relatively unchanged areas of nature and wild life, and many national parks profit from their location near state borders (Denisiuk et al. 1997) - e.g. on the Polish-Slovakian, Polish-Czech, Czech-Slovak, Slovak-Hungarian or Czech-Austrian borders (Więckowski 2013). In this part of Europe borderlands provide a good example of 'eco-frontiers' (Guyot 2011; Więckowski 2013, 2018) which are spaces where ecologists dominate (Guyot 2011).

There are many research questions and problems for future border studies concerning Central and Eastern Europe. Some of them were raised by the authors of this special issue. We could formulate them as follows:

- analysis of borders as markers of historical memory, local identity and heritage, symbolic border landscapes;

- analysis of the impact of boundaries on the everyday life of border communities, the development of routine practice of crossborder interactions, and the consequences of their disruption by border (in)security. Such interactions modified the dialectical relationship between borders' fixed nature and their constantly changing, fluid regime, and framed the impact of borders on human activities in a new way;

- cross-border shopping as an important element of everyday life, cross-border mobility and tourism; a comparative analysis with the focus on cross-border shopping tourism of different types along both the inner and

\section{References}

Alexandrova A.Yu., Stupina O.G., 2013. Turistskoe regionovedenie. Vliyanie regionalnoi integratsii na mirovoi turistskii rynok. M: Knorus.

Assmuth L., 2003. Nation building and everyday life in the borderlands between Estonia, Latvia and Russia. Focaal: European Journal of Anthropology, no. 41, pp. 59-69.

Balibar E., 2002. Politics and the other scene. London: Verso.

Bar-Kotelis D., WendT J., 2018. Comparison of crossborder shopping tourism activities at the Polish the outer borders of the EU (Szytniewska \& Spierings 2017); helping to understand the role of state borders in shaping the image of different places and cross-border mobility;

- accessibility of border areas from the central parts of neighbouring countries and their contemporary barrier functions on different scales and for different actors (Toth 2014; Więckowski et al. 2014; Michniak et al 2015);

- development of new methods (e.g GIS) in border studies;

- analysis of strategic and planning documents, marketing, promotion, cross-border regional branding in border areas; efficiency of the ENPI and INTERREG programmes in different borderlands (Dołzbłasz \& Raczyk 2015);

- impact of the migration crisis on the regime of boundaries in Central and East Europe;

- boundary management and the development of cross-border governance.

\section{Acknowledgements}

Vladimir Kolosov thanks Russian Science Foundation for supporting the project "Russian Borders: Challenges of Neighbourhood" (grant No. 14-18-03621) which allowed him analysing the progress in the theory of border studies and the evolution of borders in East Europe.

and Romanian external borders of European Union. Geographia Polonica, vol. 91, no.1, pp. 113-125.

BARWIŃSKI M., LEŚNIEWSKA K., 2014. The contemporary situation of Polish minority in Lithuania and Lithuanian minority in Poland from the institutional perspective. Geographia Polonica, vol. 87, no. 1, pp. 27-46.

BIALASIEWICZ L., 2009. Europe as/at the border: Trieste and the meaning of Europe. Social and Cultural Geography, vol. 10, no. 3, pp. 257-269.

Bıılé F., 2014. Territorial phantom pains (and other cartographic anxieties). Environment and 
Planning D: Society and Space, vol. 31, no. 1, pp. 163-178.

BOULINEAU E., 2016. La coopération territoriale entre l'union européenne et ses voisinages rientaux et balkaniques. Contribution à une géographie politique de l'européanisation. volume 1: position et projets scientifiques. Lyon: Ecole Normale Supérieure.

CinnéIDE M., 2007. Enhancing the development process in Lithuania: Toward truly participative governance [in:] S. Giguère (ed.), Baltic partnerships - Integration, growth and local governance in the Baltic Sea Region, Paris: OECD, pp. 83-108.

Coles T., Hall D., Balažz V., Williams A.M., 2005. International tourism as bricolage: An analysis of Central Europe on the brink of European Union membership. International Journal of Tourism Research, vol. 7, no. 2, pp. 79-93.

Denisiuk Z., Stoyko S., Terray J., 1997. Experience in cross-border cooperation for national park and protected areas in central Europe [in:] J.G. Nelson, R.Serafin (eds.) National parks and protected areas: Keystones to conservation and sustainable development, Berlin: Springer, pp.145-150.

DoŁzBłASz S., 2013. Cross-border co-operation in the Euroregions at the Polish-Czech and Polish-Slovak borders. European Countryside, vol. 5, no. 2, pp. 102-114.

DołzBtASZ S., 2018. A network approach to transborder cooperation studies as exemplified by poland's eastern border. Geographia Polonica, vol. 91, no. 1, pp. 63-76

DołzBłASZ S., RaCZYK A., 2015. Different bordersdifferent cooperation? Transborder cooperation in Poland. Geographical Review, vol. 105, no. 3, pp. 360-376.

Domaniewski S., StudzIŃSKa D., 2016. The small border traffic zone between Poland and Kaliningrad Region (Russia): The impact of a local visafree border regime. Geopolitics, vol. 21, no. 3, pp. 538-555.

ELDEN S., 2010. Land, terrain, territory. Progress in Human Geography, vol. 34, no. 6, pp. 799-817.

Eberhardt P., 2015. The Oder-Neisse Line as Poland's western border: As postulated and made a reality. Geographia Polonica, vol. 88, no. 1, pp. 77-105.

Eberhardt P., 2017. Political and administrative boundaries of the German state in the 20th century. Geographia Polonica, vol. 90, no. 3, pp. 335-350.

FALUDI A., 2015. Place is no man's land. Geographia Polonica, vol. 88, no. 1, pp. 5-20.

Foucher M., 1991. Fronts et frontières. Paris: Fayard.

Foucher M., 2012. L'Obsession des frontiers. Paris: Tempus Perrin.

Gorzelak G., 2006. Normalizing Polish-German Relations: Cross-Border Cooperation in Regional Development [in:] J.W. Scott (ed.), EU Enlargement, Region Building and Shifting Borders of Inclusion and Exclusion, Aldershot: Ashgate, pp. 195-206.

Grandits H., von Hirschinausen B., Kraft C., Müller D., Serrier T., 2015. Phantomgrenzen im östlichen Europa. Eine wissenschaftliche Positionierung. Göttingen: Wallstein-Verlag.

GRIN'KO I.A., 2016. 'Muzejnye granicy' i formirovanie novyh identichnostei. Samarskij nauchnyj vestnik, no. 4(17), pp. 149-152.

Gumeniyuk I.S., Kuznetsova T.Yu., Osmolovskaya L.G., 2016. Maloe prigranichnoe dvizhenie kak instrument razvitia prigranichnogo. Baltiiskii region, vol. 8, no. 1, pp. 97-117.

GUYOT S., 2011. The eco-frontier paradigm: Rethinking the links between space, nature and politics. Geopolitics, vol. 16, no. 3, pp. 675-706.

HeRrSChel T., 2011. Borders in post-socialist Europe: Territory, scale, society. Farnham: Ashgate.

Jakubowski A., Miszczuk A., Kawatko B., KomorNICKI T., SzUL R., (eds.), 2017. New borderland. Cross-border relations and regional development. Series: Regions and Cities. Regional Studies Association, Oxon-New York: Routledge.

Kolossov V., O'LoughuIN J., 1998. New borders for new world orders: Territorialities at the fin-desiecle. Geojournal, vol. 44, no. 3, pp. 259-273.

Kolosov V., Vendina O. (eds.), 2011. Rossiiskoukrainskoe pogranichie: dvadzat' let razdelennogo edinstva. Moscow: Novyi Khronograf.

Kolosov V., ScotT J., 2013. Selected conceptual issues in border studies. Belgeo, no. 1, http:// belgeo.revues.org/10532 [3 November 2017]; DOI: 10.4000/belgeo.10532.

Kolosov V., Medvedev A., Zotova M., 2018. Comparing the development of border regions with the use of GIS (the case of Russia), Geographia Polonica, vol. 91, no. 1, pp. 47-61. 
Komornicki T., Miszczuk A., 2010. Eastern Poland as the borderland of the European Union. Questionnes Geographicae, vol. 29, no. 2, pp. 55-69.

KortunOv A., 2017. Ot postmodernizma do neomodernizmam ili vospominania o budeshchem. http://www.globalaffairs.ru/number/Ot-postmodernizma-k-neomodernizmu-ili-Vospominaniya-o-buduschem-18552, published 30 January 2017 [3 July 2017].

LAINE J., 2017. Vospriatie Rossii v finskom obshchestvennom soznanii. Sravnitelnaya politika, vol. 8, no. 1, pp.123-139. DOI:10.18611 /2221-3279-2017-8-1-123-139

LeIMGRUBER W., 2005. Boundaries and transborder relations, or the hole in the prison wall. GeoJournal, vol. 64, no. 3, pp. 239-248.

LEPIK K.L., 2009. Euroregions as mechanisms for strengthening cross-border cooperation in the Baltic Sea region. Trames, vol. 13, no. 3, pp. 265-282.

Mamadoun V., 2015. Chairs' Column: Borderitis. Newsletter of IGU Commission on Political Geography, no. 19, pp. 2-5, http://www.igu-cpg.unimib.it/wp-content/uploads/2015/01/IGU-CPG_ newsletter_19_ver5.pdf. [19 September 2017].

MatTHIeSEn U., Bürkner H.J., 2001. Antagonistic structures in border areas: Local milieux and local politics in the Polish-German twin city Gubin/ Guben. GeoJournal, vol. 54, no. 1, pp. 43-50.

Michniak D., WięCKOWSKI M., StępNIAK M., Rosik P., 2015. The impact of selected planned motorways and expressways on the potential accessibility of the Polish-Slovak borderland with respect to tourism development. Moravian Geographical Report, vol. 23, no. 1, pp. 13-20.

Miszczuk A., (ed.), 2017. Wyzwania rozwojowe pogranicza polsko-ukraińskiego. Lublin: Norbertinum.

NILSSON J.K., 2018. Mobility and regionalisation: Changing patterns of air traffic in the Baltic Sea region in connection with European integration. Geographia Polonica, vol. 91, no. 1, pp. 77-93.

NILSSON J.K., EsKILSSON L., EK. R., 2010. Creating cross-border destinations: Interreg programmes and regionalization in the Baltic Sea area. Scandinavian Journal of Hospitality and Tourism, vol. 10, no. 2, pp. 153-172.

O'Loughuin J., 2001. Geopolitical visions of Central Europe [in:] M. Antonsich, V. Kolosov, M.P. Pagnini (eds.), Europe between Geopolitics and Political Geography, Rome: Società Geografica Italiana, pp. 607-628.

Palmowski T., 2010. Problems of cross-border cooperation between Poland and the Kaliningrad Oblast of the Russian Federation. Quaestiones Geographicae, vol. 29, no. 4, pp. 75-82.

Prokkola E.K., 2008. Resources and barriers in tourism development: Cross-border cooperation, regionalization and destination building at the Finnish-Swedish border. Fennia, vol. 186, no. 1, pp. 31-46.

ProkKOLA E.K., LOIS M., 2016. Scalar politics of border heritage: An examination of the EU's Northern and Southern border areas. Scandinavian Journal of Hospitality and Tourism, vol. 16, iss. suppl. 1, pp. 14-35.

RamutSIndelA M. (ed.), 2014. Cartographies of nature: How nature conservation animates borders. Newcastle upon Tyne, UK: Cambridge Scholars.

Sagan I., Kolosov V., Studzińska D., Zotova M., Sebentsov A., Nowicka K., 2018. The local border traffic zone experiment as an instrument of cross-border integration: The case of the Polish-Russian borderland. Geographia Polonica, vol. 91, no. 1, pp. 95-112.

Scom J.W., 2018. Border politics in Central Europe: Hungary and the role of national scale and nation-building. Geographia Polonica, vol. 91, no. 1, pp. 17-32.

SMETKOWSKI M., 2015. Spatial patterns of regional economic development in Central and Eastern European countries. Geographia Polonica, vol. 88, no. 4, pp. 539-556.

Sohn C., Reitel B., 2016. The role of national states in the construction of cross-border metropolitan regions in Europe: A scalar approach. European Urban and Regional Studies, vol. 23, no. 3, pp. 306-321.

STRYJAKIEWICZ T., 1998. The changing role of border zone in the transforming economies of East -Central Europe. The case of Poland. Geojournal, vol. 44, no. 3, pp. 203-213.

ŚWIATEK D., 2002. The denominational structure of the Hungarians inhabiting Slovakia. Europa XXI, vol. 7, pp. 71-75.

SzYTniewska B., Spierings B., 2017. Place image formation and cross-border shopping: German shoppers in the Polish bazaar in Stubice. Tijdschrift voor economische en sociale geografie, DOI:10.1111/tesg.12283. 
Tiмотнy D.J., 1995. Political boundaries and tourism: Borders as tourist attractions. Tourism Management, vol. 16, no. 7, pp. 525-532.

Timothy D.J., SaARinen J., Viken A., 2016. Editorial: Tourism issues and international borders in the Nordic Region. Scandinavian Journal of Hospitality and Tourism, vol. 16 , iss. sup. 1, pp. 1-13.

USHAKIN S.N., 2009. Nam etoi bol'u dyshat'? O travme, pamiati i soobshchestrakh [in:] S. Ushakin, E. Trubina (eds.), Travma: punkty. Collection of papers,. M.: Novoe Literaturnoe obozrenie, pp. 5-41.

WENDT J., 2003. Changes in the geopolitical and geostrategical position of the Kaliningrad district [in:] T. Palmowski, G. Fedorov, V. Korneevets (eds.), Economic, geopolitical and social problems of co-operation between Kaliningrad and Poland, Coastal Regions, vol. 6, Pelpin: Bernardinum, pp. 7-15.

WIĘCKOWSKI M., 2002. Polish-Slovak transboundary cooperations. Geografický časopis, 54, pp. 255-270.

WIĘCKOWSKI M., 2008. New international mobility of Poles. Espace, Populations, Societes, 2, pp. 261-270.

WIĘCKOWSKI M., 2010. Tourism development in the borderland of Poland. Geographia Polonica, vol. 83, no. 2, pp. 67-81.

WIECKOWSKI M., 2013. Eco-frontier in the mountainous borderlands of Central Europe. The case of Polish border parks. Journal of Alpine Research / Revue de géographie alpine, vol. 101, no. 2, [24 August 2017].

WIĘCKOWSKI M., 2018. Political borders under ecological control on the Polish borderlands. Geographia Polonica, vol. 91, no. 1, pp. 127-138.

WięCKOWski M., Michniak D., Bednarek-SzCZEpańska M., Chrenka B., Ira V., Komornicki T., Rosik P., Stępniak M., Székely V., Śleszýnski P., ŚWIATEK D., WIŚNIEWSKI R., 2014. Road accessibility to tourist destinations of the Polish-Slovak borderland: 2010-2030 prediction and planning. Geographia Polonica, vol. 87, no. 1, pp. 5-26.

WięCKOWskI M., CerIĆ D., 2016. Evolving tourism on the Baltic Sea coast: Perspectives on change on the Polish maritime borderland. Scandinavian Journal of Hospitality and Tourism, vol. 16, supp. 1, pp. 98-111.

Williams A.M., BaLÁŽ V., 2002. International petty trading: Challenging practices in trans-Carpathian Ukraine. International journal of Urban and Regional Research, vol. 26, no. 2, pp. 323-342.

ZHURZHENKO T., 2010. Borderlands into bordered lands. Geopolitics of identity in post-Soviet Ukraine. Stuttgart: Ibidem Verlag.

Zupančlč J., Wendt J., Ilıeș A., 2018. An outline of border changes in the area between the Baltic and the Mediterranean, their geopolitical implications and classification. Geographia Polonica, vol. 91, no. 1, pp. 33-46.
(C) Vladimir Kolosov - Marek Więckowski

(C) Geographia Polonica

(C) Institute of Geography and Spatial Organization

Polish Academy of Sciences • Warsaw • 2018
Article first received • September 2017

Article accepted • November 2017 